\title{
Farmers' Knowledge and Attitude towards the Adoption of Agroforestry Practices in Akinyele Local Government Area, Ibadan, Nigeria
}

\author{
TOKEDE, AM; BANJO, AA; *AHMAD, AO; FATOKI, OA; AKANNI, OF
}

\begin{abstract}
This study presents farmers' knowledge and attitudes towards the adoption of agroforestry in Akinyele Local Government Area of Oyo State. A multistage random sampling technique was used to administer the questionnaires to a total of 50 respondents. Data collected were analyzed using both descriptive and inferential statistics. The demographic factors analyzed showed that the majority of respondents were males $(60.8 \%)$ and possess married $(54.2 \%)$. Majority of the respondents (66\%) do not practice agroforestry and possessed low knowledge of agroforestry practices. Respondents' attitudes towards the practice were inadequate. Furthermore, knowledge of agroforestry was found to influence the willingness to adopt the practice, attitudes towards agroforestry practice also influence its adoption in the study area. Based on the findings, this study recommends that extension agents and other stakeholders should intensify effort to pass down adequate knowledge on the practice and advantages of agroforestry to farmers in the simplest form it can be well understood, to improve their attitudes and increase their rate of adoption of agroforestry practices.
\end{abstract}

DOI: $\underline{\text { https://dx.doi.org/10.4314/jasem.v24i10.10 }}$

Copyright: Copyright (C) 2020 Tokede et al. This is an open access article distributed under the Creative Commons Attribution License (CCL), which permits unrestricted use, distribution, and reproduction in any medium, provided the original work is properly cited.

Dates: Received: 15 August 2020; Revised: 22 September 2020; Accepted: 19 October 2020

Keywords: Farmers, Knowledge, Attitude, Adoption, Agroforestry and Akinyele LGA

Some centuries ago, the high forest in Nigeria was very extensive and rich in large trees. With the increase in human population, the area of the high forest started to diminish as a result of demand on forest land for farming and other forms of land use. The demand on forest conversion for alternative human use thereby results in environmental degradation and climate change challenges. Farmers depending on subsistence agriculture are most vulnerable to the effects of environmental degradation and climate change, since their lack of economic resources restricts access to alternative livelihoods (Slingo et al. 2005). In subSaharan Africa, poor crop yields are worsened by depleting soil fertility (Sanchez 2002) and climate change (Jones and Thornton 2003). Human population growth has resulted in more intensive agriculture and land use pressures. Earlier used methods of farming, like traditional fallow which lead to soil fertility are no longer in use, hence there is a lower crop yield than before (Sanchez and Swaminathan 2005), leading to increase in undernourished people and poverty (FAO 2010). There is a serious need for sustainable agricultural practices that can address these issues. A basic panacea and sustainable agriculture practice to this issue is agroforestry. Agroforestry is the integration of trees on farm and in the landscape. Agroforestry (AF) can also be defined as a dynamic, ecologically based natural resource management system, diversifies and sustains production for increased social, economic and environmental benefits (Mukadasi and Nabalegwa, 2008). AF has thus been recognized as one of the strategies to introduce indigenous and exotic trees into cropping systems and impact on livelihoods of small-holder farmers in SubSaharan Africa (Kwesiga, Akinnifesi, Mafongoya, McDermott and Agumya, 2003). Main agroforestry practices include improved fallows, taungya farming, home gardens, alley cropping, growing multipurpose trees and shrubs on farmland as well as boundary planting, (Nair, 1993 and Sinclair, 1999). Studies in several parts of Africa, including Nigeria have demonstrated the economic and agronomic returns of these practices (Franzel, Phiri and Kwesiga, 2001). Pretty, Toulmin, and Williams (2011) analysed 40 projects in 20 African countries and found that by early 2010, they had provided benefits for 10.39 million farmers and their families on roughly 12.75 million hectares of land. The role of knowledge and attitudes are very important towards the adoption of agroforestry system. Farmers' knowledge is the level of factual information and understanding that farmers have on agroforestry, how to apply it and what the outcomes are in terms of products, yield, potential environmental benefits, risks and costs. The most common and conventional knowledge system is the transfer of technology, which views desirable farming 
practice as using science-based component technologies, farmer learning as the adoption of external innovations and facilitation as the delivery of these innovations. Farm management development operates within strategic rationality and aims to support the practices of the farmer as an entrepreneur engaged in an economic enterprise focusing on the farm as a whole. The main purpose of the ecological knowledge system is to help land users to become experts at managing complex ecosystems in a sustainable manner. It assumes that farmers are experts on their own farm and take decisions based on knowledgeable interference from observation and analysis through social learning (Rolling and Jiggins 1998). The information (knowledge) the farmers have about agroforestry will likely form the basis of the attitudes they will develop towards agroforestry (Fishbein and Ajzen, 1975). The attitude of the farmers is their predisposition towards agroforestry. It is expected that a positive attitude towards agroforestry systems will increase the likelihood of adoption and a negative attitude to reduce the probability of adoption. The knowledge about agroforestry will likely determine the attitude towards it. Hence this study seeks to ascertain how farmers level of knowledge and attitude influence the adoption of agroforestry, in Akinyele Local Government area of Ibadan, with a view to increasing the rate of adoption. The study will specifically describe the socioeconomic characteristics of the respondents, assess their knowledge of agroforestry practice, examine respondents' level of adoption, verify farmers' attitudes towards adoption of agroforestry practice and ascertain the influence of knowledge and attitude on adoption of agroforestry practices.

\section{MATERIALS AND METHODS}

Study Area: The study was carried out in Akinyele local government area (LGA) of Oyo State. The study area was selected because Forestry Research Institute (FRIN) have introduced agroforestry to some wards in the LGA. The LGA is situated in western Nigeria on latitude $7^{0} 23^{\prime}$ 47' ' and longitude $3^{0} 55^{\prime} 0$ ' ' E (Akinyemi and Efenakpo, 2015). It covers an area of $518 \mathrm{~km}^{2}$, using $3.2 \%$ growth rate from 2006 census figures, the 2010 estimated population is 239,745 (NPC, 2010). The LGA is made up of 12 electoral wards: Ajibade/Alabata/Elekuru, Akinyele/Isabiyi/Irepodun, Arulogun/Eniosa/Aroro, Ijaye/Ojedeji, Ikereku, Iroko, Iwokoto/Talontan/IdiOro, Ojo, Emo/Moniya.Ojoo/Ajibode/Laniba, Olanla/Oboda/Labode, Olode/Amosun/Onidundu and Olorisa Oko/Okegbemi/Mele. It is bounded to the north by Afijiyo local government area, to the east by Osun State and Lagelu local government area, to the south by Ibadan North local government area, and to the west by Ido local government area.

Method of Data Collection and Sampling Techniques: Data for this study was collected with the aid of a structured questionnaire administered to farmers in Akinyele Local Government Area. Multi-stage sampling technique was employed in selecting the farmers in the study area. In the first stage, five (5) wards were randomly selected: Ijaye/Ojedeji, Ajibade/Alabata/Elekuru, Akinyele/Isabiyi/Irepodun, Ojo Emo/Moniya and Ojoo/Ajibode/Laniba. In the second stage, one (1) area was selected from each of the ward, Ajeja, Alabata, Akinyele, Moniya and Idowu oko. For the third stage, ten (10) farmers were selected from each of the area. This gave a total of 50 farmers.

Analytical Techniques: Data obtained were analyzed using descriptive and inferential statistics. The descriptive statistics used include frequency distribution and percentages which was used to describe the demographic characteristics and agroforestry practice status of the respondents and examine the knowledge and attitude of respondents on agroforestry area. Coefficient correlation was used to show the relationship between knowledge and willingness to practice agroforestry and also attitude and adoption of agroforestry at 0.01 level of significance.

\section{RESULTS AND DISCUSSION}

Demographic Characteristics of the Respondents: Demographic information shows the characteristics of the elements in the sample size; this helps the researcher to understand the general view of his/her respondents. A total of 50 residents from Akinyele Local Government Area filled out the questionnaire. All of the distributed questionnaires were found complete and used in the analysis. The demographic details of the participants are presented in Table 1. As shown above in Table 1, majority (78\%) of the respondents are males while the remaining $22 \%$ are females, $14 \%$ are less than 30 years of age, $24 \%$ are between $31-40$ and 51-60, while $28 \%$ are between 41 50 years. $44 \%$ of respondents had primary education, $22 \%$ had no formal education, $18 \%$ had secondary education while $16 \%$ had tertiary education. Majority $(86 \% 0$ are married while the minority $(14 \%)$ are single. $54 \%$ of the respondents practice farming on 2 4 acres of land, $24 \%$ on not more than 1 acre of land, $18 \%$ on $5-7$ acres and $4 \%$ on $8-10$ acres of land. $56 \%$ of the farmers are into mixed cropping while the remaining $44 \%$ are into mono cropping. $54 \%$ of the respondents agreed their farm land is medium, $24 \%$ small and $22 \%$ agreed their farm land is large. Table 2 below revealed the result of agroforestry practice 
status of respondents in Akinyele LGA of Ibadan. The result of the findings showed that just $17(34 \%)$ of the respondents are involved while the rest $33(66 \%)$ are not involved. The implication is that majority of the respondents are not into agroforestry practices. The result of this study supported the findings of Ndjeunga and Bantilan 2005 which revealed that despite the great potential of agricultural innovations, the uptake by smallholder farmers in Africa seems to be slow.

Table 1: Demographic Characteristics of the Participants

\begin{tabular}{|c|c|c|c|}
\hline Variables & Description & Frequency & Percentage (\%) \\
\hline \multirow[t]{2}{*}{ Sex } & Male & 39 & 78.0 \\
\hline & Female & 11 & 22.0 \\
\hline \multirow[t]{6}{*}{ Age range (years) } & $<30$ & 7 & 14.0 \\
\hline & $31-40$ & 12 & 24.0 \\
\hline & $41-50$ & 14 & 28.0 \\
\hline & $51-60$ & 12 & 24.0 \\
\hline & $61-70$ & 4 & 8.0 \\
\hline & Above 70 & 1 & 2.0 \\
\hline \multirow[t]{4}{*}{ Educational Status } & No Formal & 11 & 22.0 \\
\hline & Primary & 22 & 44.0 \\
\hline & Secondary & 9 & 18.0 \\
\hline & Tertiary & 8 & 16.0 \\
\hline \multirow[t]{2}{*}{ Marital Status } & Single & 7 & 14.0 \\
\hline & Married & 43 & 86.0 \\
\hline \multirow[t]{6}{*}{ Size of Farmland } & $>1$ acre & 12 & 24.0 \\
\hline & 2-4 acres & 27 & 54.0 \\
\hline & $5-7$ acres & 9 & 18.0 \\
\hline & $8-10$ acres & 2 & 4.0 \\
\hline & $>1$ acres & 12 & 24.0 \\
\hline & $2-4$ acres & 27 & 54.0 \\
\hline \multirow[t]{2}{*}{ Type of farming } & Mono Cropping & 22 & 44.0 \\
\hline & Mixed Cropping & 28 & 56.0 \\
\hline \multirow[t]{3}{*}{ Size of Farm } & Small & 12 & 24.0 \\
\hline & Medium & 27 & 54.0 \\
\hline & Large & 11 & 22.0 \\
\hline
\end{tabular}

Source: Computations from field work (2020).

Table 2: Agroforestry Practice Status of Participants

\begin{tabular}{lll}
\hline Agroforestry Practice Status & Frequency & Percentage (\%) \\
\hline I am involved & 17 & 34 \\
I am not yet involved & 33 & 66 \\
Total & $\mathbf{5 0}$ & $\mathbf{1 0 0}$ \\
\hline \multicolumn{2}{c}{ Source: Retrieved from field study $(2020)}$.
\end{tabular}

Table 3 below presented the participants' knowledge about agroforestry. It was shown that $100 \%$ respondents displayed accurate knowledge of items 3 and 4 i.e. responded true to items 3 and 4 (planting trees is important in agroforestry, types of trees used for agroforestry include fodder, fruit etc.). $100 \%$ of the respondents gave accurate response (false) to item 7 (agroforestry is not related to alley farming). To item 1 (Agroforestry involves planting crops amongst tree). $70 \%$ of the respondents reported true while $30 \%$ responded false. For item 5 (Agroforestry is against the practice of animal grazing), $76 \%$ responded true, while $24 \%$ responded false. To item 6 (Agroforestry systems contribute to soil infertility and erosion), just $18 \%$ responded true while $82 \%$ responded false. $70 \%$ responded true, while $30 \%$ responded false to item 8
(Agroforestry maximizes land usage). To item 9 (Agroforestry successfully integrates biodiversity conservation into agricultural landscapes on private land.), $70 \%$ responded true while the remaining $30 \%$ responded false. The implication is that all (100) respondents have accurate knowledge of what agroforestry practice is as related to items 3 (Planting trees is important in agroforestry) 4 (types of trees used for agroforestry include fodder, fruit, fuel and shelter) and 7 (agroforestry is not related to alley farming). Majority $(70 \%, 82 \%, 70 \%, 70 \%)$ gave accurate responses to the knowledge of agroforestry practice as regards items 1 (Agroforestry involves planting crops amongst tree). item 6 (Agroforestry systems contribute to soil infertility and erosion), item 8 (Agroforestry maximizes land usage) and item 9 (Agroforestry 
successfully integrates biodiversity conservation into agricultural landscapes on private land) respectively. All respondents gave incorrect response to item 2 (Agroforestry involves adoption of improved fallows), and majority $(76 \%)$ also gave incorrect response to the knowledge of agroforestry practice as regards item 5 Agroforestry is against the practice of animal grazing).
The study is supported by Matata et al., 2019 in which farmers listed a number of constraints to the adoption of improved fallows, and the main obstacles listed were lack of awareness or poor knowledge of improved fallows, unwillingness to plant trees and the inability to wait two years before getting benefits from the technology.

Table 3: Knowledge of Participants about Agroforestry

\begin{tabular}{lll}
\multicolumn{1}{c}{ Variables } & \multicolumn{2}{c}{ Frequency (Frequency in \%) } \\
& True & False \\
\hline Agroforestry involves planting crops amongst tree. & $35(70)$ & $15(30)$ \\
Agroforestry involves adoption of improved fallows. & - & $50(100)$ \\
Planting trees is important in agroforestry. & - & $50(100)$ \\
Types of trees used for agroforestry include fodder, fruit. & - & $50(100)$ \\
Agroforestry is against the practice of animal grazing. & $38(76)$ & $12(24)$ \\
Agroforestry systems contribute to soil infertility and erosion. & $9(18)$ & $41(82)$ \\
Agroforestry is not related to alley farming. & - & $50(100)$ \\
Agroforestry maximizes land usage. & $35(70)$ & $15(30)$ \\
Agroforestry successfully integrates biodiversity conservation into & $35(70)$ & $15(30)$ \\
agricultural landscapes on private land. & & \\
\hline
\end{tabular}

Source: Retrieved from analysis of field study (2020).

\begin{tabular}{|c|c|c|c|c|c|c|}
\hline Variables & $\begin{array}{l}\text { Strongly } \\
\text { Agree }\end{array}$ & Agree & Disagree & $\begin{array}{l}\text { Strongly } \\
\text { Disagree }\end{array}$ & Mean & Rank \\
\hline $\begin{array}{l}\text { Agroforestry help people to be self- } \\
\text { reliant in terms of fuel, fodder, timber. }\end{array}$ & $33(66)$ & $8(16)$ & $9(18)$ & - & 2.52 & $4^{\text {th }}$ \\
\hline $\begin{array}{l}\text { Overall income/benefits from } \\
\text { agroforestry is more than pure } \\
\text { agriculture or forestry. }\end{array}$ & $27(54)$ & $15(30)$ & $8(16)$ & - & 2.62 & $2^{\text {nd }}$ \\
\hline $\begin{array}{l}\text { Performance of trees and agricultural } \\
\text { crops in agroforestry is better than pure } \\
\text { agriculture or forestry. }\end{array}$ & $33(66)$ & $9(18)$ & $8(16)$ & - & 2.50 & $5^{\text {th }}$ \\
\hline $\begin{array}{l}\text { Agroforestry is capable of improving the } \\
\text { conditions of farmers. }\end{array}$ & $27(54)$ & $11(22)$ & $12(24)$ & - & 2.76 & $1^{\text {st }}$ \\
\hline $\begin{array}{l}\text { Agroforestry reduces the incidence of } \\
\text { crop failure. }\end{array}$ & $29(58)$ & $14(28)$ & 7 (14) & - & 2.56 & $3^{\text {rd }}$ \\
\hline
\end{tabular}

Source: Computations from field survey (2020).

The result presented in Table 4 show the attitudes of the respondents towards the practice of agroforestry. The grand mean of the attitudes of the respondents towards the practice of agroforestry was 2.59 . Of all the attitudes identified by the respondents towards agroforestry practice, improving the conditions of farmers $(x=2.76)$ was ranked $1^{\text {st }}$, while overall income/benefit from agroforestry being more than pure agriculture or forestry $(x=2.62)$ was ranked $2^{\text {nd }}$. However, reduces the incidence of crop failure $(\mathrm{x}=$ 2.56), help people to be self-reliant in terms of fuel, fodder, timber $(\mathrm{x}=2.52)$ and performance of trees and agricultural crops in agroforestry is better than pure agriculture or forestry $(\mathrm{x}=2.50)$ were ranked third fourth and fifth respectively. According to this result, only improving the conditions of farmers $(\mathrm{x}=$ 2.76) and overall income/benefit from agroforestry being more than pure agriculture or forestry $(x=2.62)$ had mean value above 2.59 the grand mean value. This indicates that improving the conditions of farmers and overall income/benefits from agroforestry being more than pure agriculture or forestry were the predisposition attitudes pushing people towards agroforestry practices in the study area.

Hypothesis Testing 1: Table 5 below revealed that the correlation coefficient table of relationship between knowledge of agroforestry and willingness to practice agroforestry is significant. The coefficient correlation (r) value is -0.387 and the significance value is 0.005 $(\mathrm{p}>0.01)$. The implication is that there is a positive correlation between knowledge of agroforestry practice and the willingness to adopt it. Adequate knowledge will promote the adoption of agroforestry practices. The study confirmed the findings of Fischer and Vasseur 2002, Sood and Mitchell 2004, Zubair and Garforth 2006, McGinty et al., 2008, Mekoya et al,. 2008, Sileshi et al., 2008b that knowledge influences adoption of agroforestry practice. Another study on the role of knowledge, attitudes and perceptions in the uptake of agricultural and agroforestry innovations among smallholder farmers in sub-Saharan Africa (Seline, Delia, Ajayi, and Sileshi, 2014) also supported the findings of this study. 
Hypothesis Testing 2: Table 6 presented the result of relationship between the attitude and adoption of respondents. It showed that there is significant relationship between respondents' attitude and the level of adoption of agroforestry. The coefficient correlation $(\mathrm{r})$ is -0.866 and the significance value is $0.00(\mathrm{p}>0.01)$. The implication is that there is a significant relationship between attitude of respondents and their level of adoption of agroforestry practices. Positive attitudes will promote the level of adoption of agroforestry practices. The study is in line with the findings of Fischer and Vasseur (2002), Sood and Mitchell (2004), Zubair and Garforth (2006), McGinty et al., (2008), Mekoya et al., (2008), Sileshi et al., (2008b) that attitude influences the adoption of agroforestry practice. Sileshi et al (2014) also supported the findings of this study in the result of their findings on the role of knowledge, attitudes and perceptions in the uptake of agricultural and agroforestry innovations among smallholder farmers in sub-Saharan Africa.

Table 5: Summary of Correlation coefficient (r) tables of the significant relationship between knowledge of agroforestry and willingness to

\begin{tabular}{clll}
\multicolumn{4}{c}{ practice agroforestry } \\
\hline Variable Description & Coefficient correlation $(\mathrm{r})$ & P-Value & Decision \\
\hline Knowledge of agroforestry and adoption agroforestry & -0.387 & $0.005^{*}$ & Significant \\
\hline Source: Retrieved from analysis of field study $(2020) .{ }^{*}$ Correlation is significant at 0.01 &
\end{tabular}

Table 6: Summary of Correlation coefficient (r) tables of the significant relationship between attitude toward agroforestry and adoption of agroforestry

\begin{tabular}{clll}
\hline Variable Description & Coefficient correlation $(\mathrm{r})$ & P-Value & Decision \\
\hline Attitude toward agroforestry and adoption of agroforestry & -0.866 & 0.000 & Significant \\
\hline Source: Retrieved from analysis of field study & $(2020) .{ }^{*}$ Correlation is significant at 0.01 &
\end{tabular}

Conclusion: The majority of the respondents do not practice agroforestry, meaning the adoption level of agroforestry in Akinyele LGA is low. Respondents' knowledge is low and attitude towards agroforestry practice is also inadequate. Knowledge of agroforestry was found to influence the willingness to adopt the practice. Also attitudes towards agroforestry practice also influenced its adoption in the study area. Extension agents and other stakeholders should intensify effort to pass down adequate knowledge on the practice and advantages of agroforestry to farmers in the simplest form.

\section{REFERENCES}

FAO (2010). The state of food insecurity in the world. Rome: Food and Agriculture Organization of the United Nations.

Fischer, A; Vasseur, L (2002). Smallholder perceptions of agroforestry projects in Panama. Agroforestry. Syst. 54 (2), 103- 113.

Fishbein, M; Ajzen, I (1975). Belief, attitude, intention, and behavior: an introduction to theory and research. Reading, MA: Addison-Wesley

Franzel S; Phiri D; Kwesiga, F (2001). Assessing the adoption potential of improved fallows in eastern Zambia. In S Franzel Scherr SJ (Eds.), Trees on the Farm: Assessing the adoption potential of Agroforestry Practices in Africa 37-64. Wallingford, UK: CAB International.
Kwesiga, F; Akinnifesi, FK; Mafongoya, PL; McDermott, MH; Agumya, A (2003). Agroforestry research and development in southern Africa during the 1990s: Review and challenges ahead. Agroforestry Systems 59: 173186

Mukadasi B; Nabalegwa, W (2008). Extension for Agroforestry Technology Adoption: Mixed Intercropping of Crotalania (crotalaniagrahamjana) and maize (zea mays L.) in Kabale District Uganda. Environ. Res. J. 2: 131-1372.

Matata, PZ; Ajayi, OC; Oduoi, PA; Aggrey, A (2010). Socio-economic factors influencing adoption of improved fallow practices among smallholder farmers in western Tanzania. Afr. J. Agric. Res. 5 (8); $818-823$

McGinty, M; Swisher, M; Alavalapati, J (2008). Agroforestry adoption and maintenance: selfefficacy, attitudes and socio-economic factors. Agroforestry. Syst. 73 (2); $99-108$.

Mekoya, A; Oosting, S; Fernanez- Rivers, S; Van det Zijpp (2008). Farmers' perceptions about exotic multipurpose fodder trees and constraints to their adoption. Agroforestry. Syst. 73 (2): $141-153$.

Ndjeunga, J; Bantilan, C (2005). Uptake of improved technologies in the semi-arid tropics of West Africa: why is agricultural transformation lagging behind? J. Agric. Develop. Econ. 2 (1), 85 -102. 
Pretty, J; Toulmin, C; Williams, S (2011). Sustainable intensification in African Agriculture. Inter. J. Agric. Sustainability. 9(1): 5-24.

Rolling, NG; Jiggins, J (1998). The ecological knowledge system. In: N.G. Ro"ling and M.A.E. Wagemakers, eds. facilitating sustainable agriculture: participatory learning and adaptive management in times of environmental uncertainty. Cambridge: Cambridge University Press, $283-311$.

Sanchez, PA; Swaminathan, MS (2005). Cutting world hunger in half. Sci. 307 (5708), $357-359$.

Seline, SM; Delia, C; Ajayi, OO; Sileshi. GW (2014). The role of knowledge, attitudes and perceptions in the uptake of agricultural and agroforestry innovations among smallholder farmers in subSaharan Africa.

DOI:
Sileshi, GW; Mafongoya, PL; Akinnifesi, FK; Phiri, E; Chinwa, PW; Beedy, T Makumda, W (2008b). Farmers' perceptions of tree mortality, pests and pest management practices in agroforestry in Malawi, Mozambique and Zambia. Agroforestry syst. 72(2): 87- 101 .

Slingo, JM; Challinor, AJ; Wheeler, TR (2005). Introduction: food crops in a changing climate. Philosophical transactions of the royal society Biological Sci. 360 (1463): 1983 -1989.

Sood, KK; Mitchell, CP (2004). Do sociopsychological factors matter in agroforestry planning? Lessons from small holder traditional agroforestry systems. Small-scale Forestry. 3 (2): $239-255$.

Zubair, M; arforth, C (2006). Farm level tree planting in Pakistan: the role of farmers' perceptions and attitudes. Agroforestry Syst. 66 (3): 217 -229. 